\title{
TEO-ONTOLOGIA PIĘKNA W PERSPEKTYWIE PÓŹNEJ NOWOCZESNOŚCl
}

\section{WSTĘP}

Jedną z charakterystycznych cech teologii współczesnej jest dowartościowanie w niej aspektu doświadczalnego, do czego w niemałym stopniu przyczyniło się odkrycie fenomenologii i egzystencjalizmu. Ów zwrot ku warstwie przeżyciowej obejmował szersze spektrum dziedzin aniżeli sama teologia. Jednym ze znamion tej przemiany wrażliwości epistemologicznej stanowi dowartościowanie estetyki. Z tego też względu nie powinien dziwić fakt, że to właśnie teologie estetyzujące, czyli takie, które jako podłoże metodologiczne wykorzystują struktury doświadczenia estetycznego, czego wyśmienitym przykładem jest chociażby teologia Hansa Ursa von Balthasara czy Karla Rahnera, stanowią prominentne przykłady teologii odznaczających się silnym ładunkiem egzystencjalnym.

* O. Jan P. Strumiłowski OCist - dr teologii dogmatycznej, wykładowca Wyższego Seminarium Duchownego w Katowicach-Panewnikach. Przeor klasztoru cysterskiego w Jędrzejowie. Zajmuje się teologią piękna, teologią trynitarną i chrystologią oraz teologiczną teorią poznania, zwłaszcza w aspekcie egzystencjalnym i estetycznym, a także jej relacjami z filozofią współczesną oraz naukami empirycznymi (jancist@gmail.com). 
Samo istnienie estetyki teologicznej, która może zostać zdefiniowana jako zabieg metodologiczny wykorzystujący strukturę doświadczenia estetycznego jako narzędzie uprawiania teologii, jest możliwe ze względu na strukturalne podobieństwo Objawienia i aktu wiary oraz doświadczenia estetycznego ${ }^{1}$. To podobieństwo dwóch różnych płaszczyzn lub zdarzeń epistemologicznych posiada jednak jeszcze głębsze ugruntowanie, które można sprowadzić do wewnętrznego podobieństwa ontologii piękna i ontologii trynitarno-chrystologicznej. Owo podobieństwo opiera się na założeniu jedności świata i jedyności Jego Stwórcy, który w swoim dziele odcisnął piętno swojego podobieństwa ${ }^{2}$. Zatem w sensie wewnętrznym stosowność wprzęgania mechanizmów estetycznych na obszar uprawiania teologii wyznacza teo-ontologia piękna wskazująca na źródłowość Boga, rozumianego jako Piękno niestworzone, względem każdego piękna stworzonego $^{3}$, zwłaszcza realizującego się w blasku Objawienia. Ta jednokierunkowa ontologiczna zależność wyznacza logiczną zależność zwrotną, dzięki której piękno staje się hermeneutą Objawienia4 ${ }^{4}$.

Włączenie estetyki, której fundamentalną cechą jest jej otwarcie na doświadczenie tego, czego nie sposób wyrazić w kategoriach pozaestetycznych ${ }^{5}$, w obręb teologii, sprawia, że teologia staje się nie tylko słowem, które może informować nas o prawdzie Bożej, ale staje się ono prawdą, której możemy poniekąd doświadczyć i zasmakować - bo taka jest natura piękna. Ponadto, estetyczne ulokowanie teologii, wyznaczone przez podstawę teo-ontologiczną osadza ją w stabilnej i racjonalnej strukturze.

Problematyczna wydaje się w tym kontekście możliwość budowania teo-ontologii na gruncie estetyk postmodernistycznych. Postmodernizm bowiem $\mathrm{z}$ jednej strony mocno koncentruje się i dowartościowuje aspekt estetyczny rzeczywistości, a z drugiej sprzeciwia się narracjom

${ }^{1}$ Por. H. U. von Balthasar, Chwała. Estetyka teologiczna, t. 1: Kontemplacja postaci, tłum. E. Marszał, J. Zakrzewski, Kraków 2008, s. 66 i n.

2 Por. J. C. Polkinghorne, Jeden Świat, tłum. M. Chojnacki, Kraków 2008, s. 12.

3 Por. K. Klauza, Teokalia. Piękno Boga. Prolegomena do estetyki dogmatycznej, Lublin 2008, s. 12.

${ }^{4}$ Por. C. Valenziano, Belezza del Dio di Gesù Cristo. Narrazione visiva del Dio invisibile, Gorle 2000, s. 114.

5 Por. A. Grzegorczyk, Humanistyka i obecność, Poznań 2014, s. 104-109. 
metafizycznym ${ }^{6}$. Z tego też względu wskazanie na możliwość istnienia teo-ontologii osadzonej w środowisku myśli ponowoczesnej odnajduje tutaj swoją doniosłość, gdyż jak się wydaje, może ono stanowić mocne współczesne dowartościowanie doświadczalnego aspektu teologii (co stanowi element zachowania niezwykle wartościowego odkrycia najnowszej teologii) z jednoczesnym przywróceniem jej stabilnej struktury ontologicznej i racjonalnej. Ponadto budowanie teo-ontologii, która jest oparta na dyskursach filozoficznych, które dokonują dekonstrukcji metafizycznego rozumienia świata, może zaowocować zbudowaniem nowego rodzaju schematu ontologicznego, stanowiącego klucz reinterpretacji dogmatów w taki sposób, by były one przystające do współczesnej mentalności, nie zatracając swojego uniwersalnego charakteru wskazywanego przez Tradycję. Innymi słowy, poszukiwanie teo-ontologi piękna przy pomocy kategorii estetycznych później nowoczesności może zaowocować skonstruowaniem nowej ontologii trynitarnej, która wpisana w przestrzeń wrażliwości epistemologicznej człowieka współczesnego mogłaby się oprzeć współczesnej krytyce myślenia metafizycznego. Taka ontologia teologiczna mogłaby stanowić rdzeń metateologicznej zasady reinterpretacji prawd objawionych w kontekście postmodernistycznym, co może stać się przyczynkiem nie tylko budowania modelu teologicznego odpowiadającego współczesnej mentalności, ale i pośrednio uzasadnia ponadkonkurencyjną naturę chrześcijaństwa.

\section{ZAGADNIENIE KLASYCZNEJ TEO-ONTOLOGII PIĘKNA}

Nie jest celem niniejszego artykułu wyczerpujące przedstawienie klasycznych modeli teologiczno-estetycznych czy opartej na nich pełnej struktury teo-ontologii ${ }^{7}$. Niemniej zręby struktury teo-ontologicznej opartej na klasycznym rozumieniu piękna są w tym miejscu niezbędne, ze względu na potrzebę zarówno wskazania fundamentalnego odniesienia kategorii

6 Por. A. Bronk, Postmodernizm, w: Leksykon teologii fundamentalnej, red. M. Rusecki, Lublin-Kraków 2002, s. 931.

7 Pełniejszego opisu teo-ontologii piękna w kontekście trynitarno-chrystologicznym dokonałem na innym miejscu (zob. J. P. Strumiłowski, Piękno zbawi świat? Soteriologiczny wymiar piękna, Kraków 2016). 
piękna do rzeczywistości Boskiej, jak i ukazania kategorii estetycznych jako skorelowanych z kategoriami ontologicznymi, które mogą być wyrażone przez prawdy dogmatyczne. Sformułowana dzięki takiemu przedstawieniu teo-ontologii piękna rozumianego tradycyjnie stanowi pewnego rodzaju podłoże dla zbudowania teo-ontologii estetyczno-posmodernistycznej.

Teo-ontologia opierająca się na klasycznym rozumieniu tego transcendentalium w swojej strukturze winna obejmować dwa najistotniejsze dogmaty chrześcijańskie, jakimi są: dogmat trynitarny i dogmat chrystologiczny ${ }^{8}$, przy czym trynitarne podstawy istnienia piękna obejmują ściśle ontologię jego wewnętrznej i istniejącej obiektywnie istoty, której pierwowzór stanowi Trójca immanentna w swoim intymnym życiu, natomiast chrystologiczne podstawy fenomenu piękna stanowią deskrypcję jego wydarzania się, wychodzenia $\mathrm{z}$ wnętrza trójjedynego życia w akcie Objawienia w Chrystusie. W dalszej części zostanie zaprezentowana estetyka integralna, której podstawę stanowi ontologia trynitarna. Niemniej sam estetyczny charakter interpretacji tejże ontologii nie pozwala na wyrwanie jej z kontekstu chrystologicznego.

Jedną z najstarszych i najbardziej powszechnych zasad estetycznych stanowi zasada nazwana przez Władysława Tatarkiewicza Wielką Teorią, która upatruję istotę piękna w obiektywnie istniejącej proporcji, harmonii i odpowiedniości ${ }^{9}$. Proporcja owa i odpowiedniość dostrzegalna w świecie jest odblaskiem tej odpowiedniości i harmonii, która w sposób najwyższy realizuje się w samym Bogu. Klasyczne rozwiązania dogmatyczne dotykające kwestii piękna jako atrybutu Boga dostrzegają, że wynika ono zarówno z doskonałej harmonii i jedności Jego przymiotów (co sugeruje pewną zewnętrzność względem Jego istoty), ale też ze względu na doskonałą jedność odrębnych hipostaz w Trójcy, co czyni Ją pięknem esencjalnym ${ }^{10}$. Piękno $\mathrm{w}$ takim kontekście nie jest prostą sumą

${ }^{8}$ Por. T. Siudy, Droga piękna w mariologii, w: Całaś piękna jest, Maryjo. Mariologia na drodze piękna, red. G. M. Bartosik, J. Karbownik, Częstochowa 2009, s. 37 i n.

9 Por. W. Tatarkiewicz, O filozofii i sztuce, Warszawa 1986, s. 179-183.

${ }_{10}$ Por. J. Pohle, Dogmatic Theology, vol. 1: God: His Knowability, Essence, and Attributes: a Dogmatic Treatise Prefaced by a Brief General Introduction to the Study of Dogmatic Theology, ed. B. Herder, St. Louis 1911, s. 269-270; Por. J. Wilhelm, T. B. Scannell, A Manual of Catholic Theology. Based on Scheeben's „Dogmatik”, vol. 1, London 1909, s. 207-208 
elementów, ale taką syntezą, dzięki której z wielości powstaje zupełnie nowa jakość, tożsama i przenikającą wszystkie spowite nią elementy. Zależność ta stanęła u progu baltazariańskiej koncepcji postaci Objawienia, która zachowując taką właśnie strukturę i dynamikę estetyczną, stanowi pewnego rodzaju objawienie wspaniałości i piękna Boga ${ }^{11}$.

Sam charakter syntetyzującej zasady estetycznej sprawia, że nie może ona być sprowadzona do czegoś stabilnego i ontologicznie zamkniętego, co zarówno z punktu widzenia estetyki filozoficznej, jak i teologii trynitarnej jest nie do pomyślenia. Bóg Trójjedyny nie jest tylko Nieporuszonym Poruszycielem, ale jest wewnętrzną, nieskończoną dynamiką miłości, która jest jednocześnie źródłem tożsamości Osób (Ojciec jest Ojcem ze względu na dynamikę rodzenia Syna; Syn jest Synem ze względu na dynamikę otrzymywania istnienia, bycia rodzonym oraz oddawania wszystkiego Ojcu itd.). Trójca zatem nie jest arytmetyczną sumą trzech hipostaz, ale jest jednością natury w trzech dynamicznie warunkujących się subsystencjach. W perspektywie estetycznej zależność tę wyznacza moment doświadczenia piękna, który jest momentem syntezy opartej na podobnych zasadach. Doświadczenie piękna jest związane z dostrzeżeniem harmonii dzieła na wszystkich jego płaszczyznach. W dziele bowiem wszystkie jego elementy utrzymują relacje zarówno względem siebie nawzajem, jak i całości dzieła. Idealne zestrojenie wszystkich możliwych zależności, które zdecydowanie przekraczają samą strukturę dzieła i które determinują powstawanie nadzanaczenia całości dzieła na styku różnych harmonijnych konfiguracji powiązań znaczeniowych, skutkuje właśnie doświadczeniem piękna ${ }^{12}$.

Dostrzeżenie tej zależności pokazuje, że zasada wielości w jedności, będąc zasadą ontologiczną, w swoim estetycznym znaczeniu zakłada pewnego rodzaju ontologię dynamiczną, co w ontologii trynitarnej odnajduje swoje podglebie w prawdzie, według której dla prawidłowej interpretacji tegoż dogmatu nie wystarczy uchwycenie strukturalnej zależności między trzema hipostazami w jednej naturze, ale niezbędne jest uchwycenie

${ }^{11}$ Por. A. Nichols, Redeeming Beauty. Soundings in Sacral Aesthetics, Burlington 2007, s. 56.

12 Por. L. Pareyson, Estetyka. Teoria formatywności, tłum. K. Kasia, Kraków 2009, s. 122 i n. 
dynamizmu wewnętrznego życia, gdyż w Trójjedynym dynamika wewnętrznego życia i ontologia hipostaz $\mathrm{w}$ ich relacjach są $\mathrm{w}$ najwyższym stopniu tożsame. Bóg Trójjedyny bowiem w swojej istocie jest totalnym "procesem” wyrażania siebie ${ }^{13}$ oraz totalnym i nieustannym zachwytem nad tym, co zostaje wyrażone ${ }^{14}$. Wcielenie i Objawienie jest tymczasem uzewnętrznieniem tej wewnątrztrynitarnej estetyki. Chrystus w takiej perspektywie nie tylko objawia prawdę o Bogu, ale On sam w sobie jest tą prawdą i to nie tyle i nie tylko w jej wymiarze treściowym, ale także $\mathrm{w}$ jej wymiarze istotowym i egzystencjalnym. Wydarzenie Chrystusa jest Objawieniem miłosnego rodzenia Syna w świecie, co stanowi o istocie Jego piękna.

W zarysowanej w ten sposób teo-ontologii dostrzec możemy pewnego rodzaju konieczność istotowego powiązania poszczególnych prawd wiary. Jeśli dogmat chcemy poddać interpretacji estetycznej, co ma doprowadzić do odkrycia głębszych jego pokładów znaczeniowych, a ponadto ma pozwolić na dotarcie nie tylko do jego treści, ale i do jego dynamiki ontologiczno-ekonomicznej, to sama interpretacja estetyczna wskazuje, że dla wydobycia tak rozumianego integralnego znaczenia nieodzowne jest pewnego rodzaju spojrzenie holistyczne na prawdy wiary (analogia fidei), co w estetyce wynika już z samej klasycznej zasady sformułowanej w Wielkiej Teorii. W myśl tej zasady nie tyko błędnie interpretujemy dogmat trynitarny, stosując oddzielną interpretację poszczególnych hipostaz, ale też błędem jest odczytywanie dogmatu trynitarnego bez kontekstu chrystologicznego i odwrotnie, co jak najbardziej jest zgodne z dynamiką krystalizowania się i kodyfikacji treści objawienia w czasach patrystycznych ${ }^{15}$. Zależność ta posiada zarówno charakter wewnętrzny

13 Por. R. J. Woźniak, Różnica i tajemnica. Objawienie jako teologiczne źródło ludzkiej sobości, Poznań 2012, s. 201-202.

14 Por. N. Valentini, Sui sentieri interrotti della Bellezza, w: Cristianesimo e bellezza. Tra Oriente e Occidente, ed. N. Valentini, Milano 2002, s. 9-10.

${ }_{15}$ Prawda trynitarna dotycząca wewnętrznego życia Boga nie została nam objawiona jako prawda abstrakcyjna, ale jako zapośredniczona w wydarzeniu Jezusa Chrystusa. Stąd wczesne spory chrystologiczne i trynitarne są ze sobą powiązane i wewnętrznie wzajemnie zdeterminowane (por. J. Pelikan, Tradycja chrześcijańska. Historia rozwoju doktryny, t. 1: Powstanie wspólnej tradycji (100-600), tłum. M. Höffner, Kraków 2008, s. 182). 
(ontologiczny), jak i zewnętrzny (logiczny), co sprawia, że izolowane omawianie tych dogmatów z gruntu prowadzi do redukcji Bożej prawdy. Oznacza to, że zasada tożsamości Trójcy ekonomicznej i immanentnej ${ }^{16}$ jest zasadną nie tylko logiczną, ale też ontologiczną. W takiej perspektywie chrystologia oraz epifanijne wydarzenie Chrystusa same w sobie stanowią hermeneutykę prawdy trynitarnej. Zależność taką zauważyć możemy zresztą chociażby w estetyce teologicznej von Balthasara, dla którego postać Chrystusa bądź w szerszym kontekście chrystokształtna postać Objawienia w swojej estetycznej strukturze daje nam przystęp do prawdy trynitarnej ${ }^{17}$, co realizuje porządek epistemologiczny Objawienia. Natomiast w porządku ontologicznym, który de facto wyznacza porządek epifanijny, porządek wewnątrztrynitarnej ekspresji ugruntowany $\mathrm{w}$ istocie Boga stanowi matrycę wszelkiej samoekspresji, przez co ekspresja na zewnątrz (Objawienie) jest niesiona przez ekspresję wewnątrztrynitarną (intymne życie wewnętrzne Trójcy) ${ }^{18}$. Chrystologia stanowi zatem hermeneutykę trynitologii.

Estetyka zbudowana w ten sposób wydaje się otwierać wewnętrzne granice poszczególnych dogmatów, osadzając je w przestrzeni pewnej metazasady teologicznej, co sprawia, że teologia uprawiana w tymże kluczu broni się przed zdefiniowaniem jej w skostniałych ramach stabilnej i domkniętej ontologii, przed którą sprzeciw zgłasza postmodernizm. Niemniej nie dyskredytuje ona samej narracji metafizycznej, co stanowi jej wartość, wskazując na przystawalność metafizycznej struktury dogmatu z jej dynamicznym aspektem wyrażanym poprzez kategorie estetyczne.

Takie powiązanie dynamizmu estetycznego z metafizycznym rygoryzmem sprawia, że podjęcie podobnej analizy dogmatycznej w kluczu modeli filozoficznych nacechowanych jeszcze mocniejszym ładunkiem estetycznym, jakich przykład stanowią systemy ponowoczesne, może w kontekście teologicznym dowieść, że owo estetyczne dowartościowanie nie musi prowadzić do destrukcji metafizyki, a jedynie przynosić jej

${ }^{16}$ Por. K. Rahner, Teologia $i$ antropologia, w: tenże, Pisma wybrane, t. 1, tłum. G. Bubel, Kraków 2005, s. 47.

17 Por. H. U. von Balthasar, Chwała..., t. 1, s. 22 i n, 132-146, 375-459.

18 Por. tenże, Chwała. Estetyka teologiczna, tom 2: Modele teologiczne, część 1: Od Ireneusza do Bonawentury, tłum. E. Marszał i J. Zakrzewski, Kraków 2007, s. 280 i n. 
transformację lub redefinicję, gdyż jak pokazuje to powyższy przykład, estetyka nie wyklucza metafizyki, ale ją zakłada.

\section{DEKONSTRUKCJA JAKO POSTMODERNISTYCZNA ESTETYKA ROZBIJAJĄCA ONTOLOGIĘ}

Estetyka w rozumieniu klasycznym jest dziedziną zajmującą się pięknem zarówno pod względem epistemologicznym, jak i ontologicznym. Zatem w pewnym sensie może ona być swoistą ontologią piękna pojmowanego źródłowo, a także może koncentrować się na przejawach piękna oraz strukturze ontologicznej umożliwiającej przejawianie się piękna w tym, co estetyczne, np. w sztuce ${ }^{19}$. W końcu estetyka może do zagadnienia piękna podchodzić w sposób epistemologiczny lub fenomenologiczny, koncentrując się na doświadczeniu piękna ${ }^{20}$. Tak szerokie spektrum formalnych ujęć tematu estetyki wynika z natury przedmiotu, którym estetyka się zajmuje, a którym jest piękno.

Dekonstrukcja w swojej istocie tymczasem jest pewnego rodzaju strategią ontologiczno-epistemologiczną, która dostrzegając zależność między sferą znaczeń i sferą znaków niosących owe znaczenia, zauważa między nimi rozdźwięk i niejednoznaczność. Stąd dekonstrukcja programowo rezygnuje z poszukiwania jedynego uniwersalnego i obiektywnego sensu niesionego przez zespół znaków (w naszym wypadku strukturę estetyczną), badając, w jaki sposób architektura konkretnego obiektu umożliwia jego wieloznacznośćc1 (która niewątpliwie jest kategorią estetyczną) poprzez generowanie, a nie odtwarzanie sensu związanego ze znakami, z których się on wydobywa.

Bardzo mocno $\mathrm{z}$ tym opisem korespondują różne opisy doświadczenia estetycznego, według których jest ono doświadczeniem doskonałej syntezy, w której nieskończone przeciwieństwa odnajdują swoją jedność

19 Por. W. Tatarkiewicz, Historia estetyki, t. 1, Warszawa 2009, s. 9.

${ }^{20}$ Por. G. Pöltner, Estetyka filozoficzna, tłum. J. Zychowicz, Kraków 2011, s. 14 i n.

${ }^{21}$ Por. Literatura Europy. Historia literatury europejskiej, red. A. Benoit-Dusausoy, G. Fontaine, tłum. M. Kurek, Gdańsk 2009, s. 887 
w skończonym dziele ${ }^{22}$. W ten sposób np. syntetyzująca istota sztuki sprawia, że dzieło może być przedmiotem nieskończonego ciągu interpretacji ${ }^{23}$, a jako takie jest pewnego rodzaju nieskończonością wyrażoną w obszarze skończoności ${ }^{24}$. Z tego też względu obiekty wieloznaczne, jak zauważa Alexander Gottlieb Baumgarten są bardziej nasycone estetycznie od jednoznacznych. Charakteryzują się one większą rozległością poznawczą ${ }^{25}$.

Zasadą estetyczną w wieloznaczności jest tożsamość w rozmaitości. To ona przyciąga uwagę człowieka i nawołuje do ciągłych powrotów i ciągłego spoglądania z różnych punktów widzenia. Fakt niewyczerpalności znaczeniowej jest podniecający dla umysłu. Rzecz piękna jest jak radioaktywne źródło, które nie generuje nowych, odrębnych znaczeń, ale nieustannie pogłębia i wysyła znaczenia kompatybilne do swojej istoty ${ }^{26}$.

Podobny charakter $\mathrm{z}$ fenomenologicznego punktu widzenia znamionuje dekonstrukcję, która jest jakby syntezą fenomenologicznego opisu doświadczenia percepcji wieloznacznych sensów powstałych na styku tego, co poznawane, i tego, który poznaje, oraz struktury w jej dynamice umożliwiającej ową multiznaczeniowość. Dekonstrukcja tym samym zakłada nieustanne i dynamiczne konfigurowanie znaczeń w świecie, który przez fakt owej płynności nie sposób sprowadzić do modelu statycznego ${ }^{27}$. Estetyczny charakter tej koncepcji podkreśla również fakt, że powstała ona na polu refleksji teoretyczno-literackiej jako koncepcja opisująca estetyczność literatury pięknej ${ }^{28}$.

Konstytutywnym terminem dekonstrukcji jest różnica (franc. différance), która oznacza i opisuje istotowo uprzedni względem języka ruch

${ }^{22}$ Por. R. Kasperowicz, Figury zbawienia? Idea „religii sztuki” w wybranych koncepcjach artystycznych XIX stulecia, Lublin 2010, s. 138.

${ }^{23}$ Por. tamże, s. 139.

${ }^{24}$ Por. tamże, s. 141.

25 Por. M. Żelazny, Estetyka filozoficzna, Toruń 2009, s. 29.

${ }^{26}$ Por. R. Sokolowski, Wprowadzenie do fenomenologii, tłum. M. Rogalski, Kraków 2012, s. 181-183.

27 Por. M. P. Markowski, Dekonstrukcja, w: Teorie literatury XX wieku, red. A. Burzyńska i M. P. Markowski, Kraków 2009, s. 362.

${ }_{28}$ Por. B. D. Kwiatkowski, Fragmentaryzacja nadziei w kulturze ponowoczesnej, „Teologia w Polsce” 4 (2010) 1, s. 99. 
konstytuujący znaczenia. To różnica jako dynamiczna przestrzeń między konkretnymi znakami determinuje ich treśćc ${ }^{29}$. Różnica zatem jest pewnego rodzaju konstytutywną przyczynowością, źródłową i wytwórczą zmierzającą do nadania znaczeniowych granic, realizujących się w określonym znaczeniu $^{30}$. Nie posiada jednakże statusu ontologicznego ${ }^{31}$.

Dekonstrukcja ontologiczna, której dokonuje Jacques Derrida, wprowadzając pojęcie różnicy, niewątpliwie opisującej z fenomenologicznego punktu widzenia poznawcze konstytuowanie się znaczeń, polega na tym, że znaczenia nie są związane z obiektywnym statusem ontologicznym świata, na co wskazywałyby jasne i wykrystalizowane pojęcia o świecie, jakimi się posługujemy, ale powstają w sposób dynamiczny w przestrzeni własnych wewnętrznych odniesien' ${ }^{32}$ na styku odniesienia do tego, który poznaje $e^{33}$.

W kontekście epistemologicznym może to prowadzić do pewnego rodzaju negatywizmu poznawczego, który mówi nam, że nasze poznanie jest mocno determinowane przez podmiot poznający lub - jak to sugeruje dekonstrukcja - że ono jest właściwie wytwarzane w procesie poznania, a to, co nazywamy jego obiektywnym, ontologicznym znaczeniem, jest jedynie wypadkową procesu poznawczego, a nie skutkiem obiektywnej, ontologicznej struktury. Dekonstrukcja demaskuje zatem wąłłość metafizycznych fundamentów stojących u progu wielkich systemów filozoficznych przeszłości ${ }^{34}$.

W kontekście teologicznym, adaptując wprost estetyczny mechanizm dekonstrukcji do dynamiki Objawienia i wiary, zauważyć możemy, że doskonale tłumaczy on nadobfitość i niezgłębioność ich treści, ale jednocześnie wydaje się, że kwestionuje obiektywny porządek ontologicz-

${ }^{29}$ Por. J. Derrida. Różnia (difference), tłum. J. Skoczylas, w: Drogi wspótczesnej filozofii, red. M. Siemek, Warszawa 1978, s. 409.

30 Por. Tamże, s. 382.

31 Por. Tamże, s. 402.

32 Por. Tamże, s. 309-411.

${ }_{33}$ Por. B. Johnson, The Critical Difference: Essays in the Contemporary Rhetoric of Reading, Baltimore 1980, s. 5.

${ }^{34}$ Por. A. Kopka, O logocentryzmie, czyli wstęp do zrozumienia filozofii Jacques'a Derridy, „Zeszyty Naukowe Towarzystwa Doktorantów UJ, Nauki Humanistyczne”, 5 (2012) 2, s. 57. 
ny Objawienia, co stanowi poważny problem recepcji dekonstrukcji na grunt teologiczny. Czy jednak na pewno teologia dekonstruktywna uderza w status ontologiczny prawd objawionych, czy jedynie prawidłowo ustawia je względem kategorii ontologicznych znamionujących świat stworzony?

\section{DEKONSTRUKTYWNA ESTETYKA TEOLOGICZNA JAKO MODEL TEO-ONTOLOGII OTWARTEJ}

Stabilna struktura ontologiczna w myśl dekonstrukcji nie istnieje sama w sobie, ale jest pewnego rodzaju wirtualnym, stabilnym obrazem mieszczącym dynamizm znaczenia, uchwycony przez odbiorcę. Świat $\mathrm{w}$ dekonstruktywnej interpretacji jest światem krystalizującym się w zetknięciu z człowiekiem, co sprawia, że z perspektywy antropologicznej jego kształt ustala się w dynamicznym procesie doświadczania (poznania) świata. Wydaje się zatem, jakoby nie miał on stabilnej konstytucji ontologicznej.

W dekonstruktywnym podejściu do ontologii na gruncie teologii nie powinniśmy się jednak bać jakkolwiek nieortodoksyjnie brzmiącej negacji stabilnej struktury ontologicznej jako obiektywnie istniejącej. Co więcej, dekonstrukcja w perspektywie teologicznej może przyczynić się do otwarcia ontologii, która tłumaczy istnienie świata w kontekście istnienia Boga przy uwzględnieniem radykalnej różnicy ich natur.

Dekonstrukcja wyrosła na gruncie doświadczenia i jego analizy, która pokazała, że w doświadczeniu nie mamy do czynienia ze stabilną rzeczywistością, ale raczej ze strumieniem potencji znaczeniowych, które w procesie poznawczym ulegają względnej krystalizacji. Podobnie rzecz ma się ze strukturą Objawienia. Jedyne doświadczenie Boga, jakie posiada człowiek, jest doświadczeniem Jego ekonomii ${ }^{35}$. I nawet jeśli owo doświadczenie jest zobiektywizowane (Pismo i Tradycja), to jest to jednak cały czas zobiektywizowany zapis doświadczenia Boga ekonomicznego. Doświadczenia ontologii Boga nie posiadamy wcale, co wynika z różnicy natur dzielącej Boga i człowieka. Obraz ontologiczny Boga jest obrazem

35 Por. Historia dogmatów, red. B. Sesboüé, t. 1: Bóg zbawienia, tłum. P. Rak, Kraków 1999, s. 283. 
wtórny, a jego absolutna przystawalność i adekwatność do Boga doświadczanego ekonomicznie, którą postuluje Rahner ${ }^{36}$, wynika z prawdy o absolutnej prostocie Boga. $\mathrm{Z}$ onto-logicznego punktu widzenia nie jest możliwe, żeby działanie Boga nie było z Nim tożsame, gdyż w takim przypadku nie byłoby Jego działaniem.

W takiej perspektywie dekonstrukcja poddaje się reinterpretacji teologicznej w takim znaczeniu, że nie tyle neguje ontologiczny status Boga, ile stwierdza, że człowiek sam w sobie nie może mieć do niego dostępu. Jedyne, czego człowiek może doświadczyć, to różnica, która w myśl dekonstrukcji na jednym krańcu delimituje znaczenie i tożsamość świata oraz człowieka, a na drugim delimituje, jeśli można to tak ująć „znaczenie” Boga. Oczywiście człowiek w takim układzie, jako lektor rzeczywistości, jest także elementem jej „tekstu”, przez co odczytanie „znaczenia Boga" jest obciążone fragmentarycznością ludzkiej perspektywy. Stąd też to, co nazywamy Bogiem immanentnym, a co rozumiemy jako ontologiczny model trynitarny, jest w gruncie rzeczy modelem zbudowanym według kategorii wyznaczonych przez ontologię, która jest skutkiem różnicy między Bogiem a człowiekiem. Innymi słowy nasze orzekanie o Bogu jest orzekaniem podług naszych, stworzonych kategorii, a nie kategorii rzeczywiście znamionujących Boga, gdyż tych nie znamy. I teologia też zdaje sobie $z$ tego sprawę, o czym daje wyraz w swojej świadomości apofatycznej. Jednak zdaje sobie również sprawę z możliwości budowania takiego modelu, który jednocześnie w naszym ujęciu jest analogiczny do Boga takiego, jakim On jest. A analogia jest możliwa, gdyż różnica między Bogiem a stworzeniem ma dwojaki charakter. Po pierwsze, delimituje ontologię stworzenia jako radykalnie inną od ontologii Stwórcy, przez co nasze mówienie o Bogu jest obciążane nieprzystającymi kategoriami. Po drugie, ontologia Boga, której nie znamy, jest tożsama z Jego ekonomią ${ }^{37}$, którą możemy rozpoznać, co sprawia, że jednak nasze orzekanie o Bogu jest adekwatne. Zatem chrześcijańska zasada głosząca, że „pomiędzy Stwórcą a stworzeniem nie można dopatrzeć się tak wielkiego podobień-

${ }^{36}$ Por. Mały słownik teologiczny, red, K. Rahner i H. Vorglimler, tłum. T. Mieszkowski i P. Pachciarek, Warszawa 1987, kol. 504.

37 Por. C. Smuniewski, Wspólnota łaski. Charytologiczno-trynitarna eklezjogeneza, Kraków 2013, s. 185. 
stwa, żeby nie trzeba było widzieć większej pomiędzy nimi różnicy"38, któremu daje wyraz chrześcijańska teoria analogii bytu ${ }^{39}$, jest zasadą realizującą założenia dekonstrukcji.

$\mathrm{Na}$ jeszcze innej płaszczyźnie podobieństwo chrześcijaństwa do dekonstruktywnej natury świata zauważał Jean-Luc Nancy, który dostrzegając, że chrześcijaństwo w swoich założeniach mieści największe paradoksy i w swojej istocie jest ich syntezą, zauważył też, że posiada dekonstruktywną naturę. W perspektywie tej prawdy jakoby dekonstrukcja była częścią definicji chrześcijaństwa, Nancy pytał wprost, czy nie należy mniemać, że w pewnym sensie chrześcijaństwo, jako szczególny rodzaj dekonstrukcji, jest wszędzie $^{40}$. Dla Nancy'ego chrześcijaństwo samo w sobie jest dekonstruktywnym wydarzeniem, nieustannym stawaniem się, esencjalnym wymogiem otwarcia tego świata na bezwarunkową inność i alienację ${ }^{41}$.

Widzimy zatem wyraźnie, że dekonstrukcja w perspektywie teologicznej nie tyle niszczy narrację metafizyczną, ile ją pogłębia, nie pozwalając sprowadzić narracji o Bogu do zaledwie ludzkich kategorii. Co więcej, sama struktura percepcji zakładającej, że człowiek jest zarówno odbiorcą, jak i dziełem różnicy pomiędzy nim a Bogiem, dokonuje pewnego rodzaju otwarcia ontologicznego, które możemy odczytywać na dwojaki sposób, tzn. z perspektywy zewnętrznej, ogarniającej całość systemu Bóg - różnica - świat, oraz z perspektywy ludzkiej, czyli z wnętrza systemu, z punktu widzenia stanowiącego system elementu.

Patrząc z punktu widzenia całości systemu, widzimy, że człowieczeństwo jest ufundowane poprzez różnicowanie względem Boga ${ }^{42}$. Kontekst teologiczny domaga się jednak dookreślenia, według którego różnica nie jest ontologicznie autonomiczna względem Boga ani człowieka, czemu

38 Por. Sobór Laterański IV, Konstytucje, nr 2,7, w: Dokumenty soborów powszechnych, t. 2, tłum. A. Baron, Kraków 2003: „inter creatorem et creaturam non potest tanta similitudo notari, quin inter eos maior sit dissimilitudo notanda”.

39 Por. B. Mondi, The Principle of Analogy in Protestant and Catholic Theology, Hague 1963, s. 62-84.

${ }^{40}$ Por. Ch. Watkin, Neither/Nor: Jean-Luc Nancy's deconstruction of christianity, "Research in Phenomenology", 37 (2007), s. 138.

${ }^{41}$ Por. J.-L. Nancy, La déclosion (Déconstruction du christianisme, 1), Paris 2005, s. 20 .

${ }^{42}$ Por. R. J. Woźniak, Różnica i tajemnica, s. 297-363. 
zadość czyni chrześcijańskie pojęcie Boskiej ekonomii. Człowiek zatem z całościowego punktu widzenia (obejmującego cały chrześcijański proces dekonstrukcji) jest elementem totalnej i pełnej struktury ontologicznej ${ }^{43}$, wewnątrz której dzieje się różnicowanie (stwarzanie) świata względem Boga. Struktura taka może jak najbardziej posiadać ustalony status ontologiczny (a właściwie metaontologiczny), chociaż nie w rozumieniu statycznym, ale na wskroś dynamicznym. Spojrzenie takie potwierdza zatem, że w swojej istocie Bóg jest actus purus ${ }^{44}$.

Absolutny charakter Boga, który wyraża się w tym, że mimo wpisania w omawianą strukturę nie może stanowić On jedynie podrzędnego elementu systemu podporządkowanego różnicy, ale jest On dla różnicy współistotny (oczywiście w kontekście dekonstruktywnej analizy faktu stworzenia i objawienia), sprawia, że winien być On postrzegany zarówno jako Bóg różny od człowieka i stojący naprzeciw swojego stworzenia, a także jako Bóg wszechogarniający, przenikający i konstytuujący (różnicujący) człowieka. Schemat taki ponadto realizuje klasyczną zasadę trynitarną, zakładającą odrębność w jedności, w którą stworzenie wydaje się wpisane. Dzięki takiemu ustawieniu kwestii doświadczenie Boga jest możliwe, jednak nie w ontologicznej bezpośredniości, a poprzez różnicę w zapośredniczeniu antropologicznym. Bóg, jakiego doświadczamy, to nie Bóg ontologiczny, ale ekonomiczny. Stąd doświadczenie Boga siłą rzeczy musi w poznaniu człowieka rodzić obraz dynamiczny.

Zaproponowany opis jest opisem hipotetycznym, w którym próbujemy ogarnąć całość systemu (Bóg - różnica - świat) jakby z zewnątrz, z konsekwentnym uwzględnieniem natury wszystkich elementów systemu. Doświadczenie, jakie posiadamy, pochodzi jednak z wnętrza systemu, którego charakter jest dyktowany naturą jego całości. Dlatego też patrząc z punktu widzenia człowieka, winniśmy być świadomi, że człowiek jest jednym z elementów tej konstrukcji - dlatego nasz ogląd jest zredukowany. $\mathrm{Z}$ tego też względu nie powinno dziwić, że ontologia ufundowana

${ }^{43}$ Owa struktura ontologiczna nie posiada znamion charakteryzujących znane nam klasyczne ontologie opisujące zasady bytu stworzonego. Jest to raczej rodzaj metaontologii, odnoszącej się do istnienia rzeczywistości absolutnej, a przez to też mieszczącej w swoim obrębie nasze klasyczne ontologie jako jej warianty, czyli pewnego rodzaju subontologie.

${ }^{44}$ Por. K. Góźdź, Bóg jako istnienie osobowe, „Teologia w Polsce”, 5 (2011) 1, s. 27. 
teologicznie z punktu widzenia antropologicznego wydaje się faktycznie płynna i totalnie przekraczająca możliwości poznawcze człowieka, gdyż człowiek nie może mieć doświadczenia Boga (a właściwie całego systemu) z zewnątrz, takiego jakim On jest sam w sobie.

Człowiek ma przystęp do jego poznania przez fakt, że jest włączony w jego różnicującą dynamikę (ekonomię) i dlatego ogląda go de facto od wewnątrz ze swojego antropologicznego punktu widzenia, co sprawia, że nie ogarnia jego całości, a jedynie jego dynamiczne konfigurowanie się względem własnego podmiotu, który jest zarówno elementem, jak i perceptorem, lecz nie posiada zdolności oglądu absolutnego i zewnętrznego (obiektywnego).

Z punktu widzenia człowieka Bóg, którego człowiek doświadcza, jest zatem Bogiem niezmierzonym, a Jego ontologia $\mathrm{z}$ epistemologicznego punktu widzenia wydaje się ontologią otwartą. Człowiek doświadczający ekonomii (różnicy) doświadcza Boga w Jego stwórczym i odkupieńczym działaniu względem siebie. Sam Bóg jawi się w takiej perspektywie jako nieustannie samoudzielający się człowiekowi, jako źródło, którego nie sposób ogarnąć, wyczerpać i zgłębić, co w człowieku doświadczającym Boga konkretyzuje się w poznaniu przybierającym kontury ontologiczne, które jednak pozostają otwarte w swojej przepastnej głębi. Tak rozumiana otwartość ontologiczna jest podyktowana faktem doświadczania Boga z wnętrza systemu przez podmiot, który posiada faktycznie charakter jego elementu ${ }^{45}$. Spojrzenie od wewnątrz uwidacznia również prawdę, że także różnica, w kontekście naszego świata rozumiana jako ekonomia, a także samo stworzenie świata i człowieka są skutkiem otwartości ontologicznej Boga. Z punktu widzenia epistemologicznego zaś skutkiem owej otwartości jest możliwość Jego poznania oraz sam charakter tego poznania, który nie ma końca, co już usiłowali wyrazić ojcowie Kościoła ${ }^{46}$.

${ }^{45}$ Klasycznie taki status ontologiczny wyraża prawda o przygodności i skończoności stworzenia.

${ }^{46}$ Niezmierność owego poznania Boga nie charakteryzuje się nieskończoną rozległością treściową, która powodowałaby poznawanie coraz to nowych prawd o Bogu, ale rozległością głębi, co oznacza, że prawda Objawiona w całości w nieskończoność może być pogłębiana i coraz bardziej doskonale pojmowana. Taki charakter znamionuje teologiczne poznanie Boga, o którym mówi chrześcijańska tradycja mistyczna, począwszy od Grzegorza z Nyssy (por. J. Danieilou, Platonisme et theologie mystique, Paris 1944, s. 305-307). 
Stabilizacja ontologii w naszym poznaniu intelektualnym jest natomiast jedynie schematycznym i wynikającym z natury ludzkiego poznania ustabilizowaniem doświadczenia Boga. Bez świadomości faktu, że każdy tak skonstruowany model nie jest czymś faktycznym, ale schematycznym (a w zasadnie uproszczonym i nieprawdziwym), tworzymy jedynie antropomorficznego idola nieprzystającego do Boga żywego ${ }^{47}$, gdyż Bóg faktycznie jest nieskończoną dynamiką obdarowywania człowieka sobą. Stanowi ono zatem nic innego jak wyrażenie doświadczenia nieskończonego i absolutnego Boga we własnych kategoriach skończoności i przygodności ${ }^{48}$. Z punktu widzenia człowieka jako elementu tak rozumianego Boskiego systemu różnicującego doświadczana rzeczywistość Boska musi być z konieczności otwarta.

Teologie estetyzujące, które wyrosły na gruncie naukowego zwrotu estetycznego, a które dowartościowują moment egzystencjalny poznania Boga, stanowią, jak widać, rdzeń budowania pomostu łączącego klasyczne modele ontologiczne z fenomenologicznymi. Wewnętrzna struktura doświadczenia estetycznego zaadaptowana na grunt teologiczny, pozwala na dowartościowanie doświadczenia bez rezygnacji z koncentracji na stabilnej konstrukcji ontologicznej wyznaczającej doświadczenie Boga.

$\mathrm{Na}$ tej estetycznej podstawie możliwe jest poszukiwanie porozumienia z dyskursami filozoficznymi, które z jednej strony odznaczają się dużym ładunkiem ontologicznym, a z drugiej wydają się kontestować narracje metafizyczne. Aplikacja ich struktur w przestrzeń teologiczną

47 Por. J.-L. Marion, Lidole et la distance, Paris 1977, s. 22-37.

48 Nie oznacza to, że mówiąc o Bogu, którego doświadczamy, przydajemy mu cech skończoności i przygodności, ale że wyrażamy się o jego nieskończoności i wieczności w kategoriach ontologicznych zaczerpniętych z rzeczywistości nam znanej - czyli naznaczonej owymi cechami. Stąd nasze orzekanie o Bogu jest nacechowane opozycyjnym językiem negatywnym, według którego, skoro człowiek jest skończony, to Bóg jest nieskończony, co oczywiście jest prawdą. Takie określenie mówi nam o inności Jego natury względem naszej skończoności, ale nie mówi nam o Jego własnej naturze w sobie. Pojęcie nieskończoności budowane na zasadzie opozycji (ciągłego przekraczania skończoności) jest natomiast jedynie pojęciem analogicznym (wyrażonym w kategoriach naszej ontologiczności) względem faktycznej nieskończoności Boga, której nie znamy. 
okazuje się nie tylko dowartościowywać (wydobywać z teologii) aspekt doświadczalny, ale i pogłębiać refleksję metafizyczną, zamiast ją niszczyć. Owo pogłębienie metafizyczne zaś, jak się okazuje, koresponduje z samą strukturą fenomenu Objawienia.

Streszczenie. Teo-ontologia piękna w perspektywie późnej nowoczesności. Współcześnie słusznie zwraca się uwagę, że teologia nie może być tylko intelektualnym roztrząsaniem treści objawienia, ale powinna wiązać się z konkretnym przeżyciem chrześcijaństwa. Ten egzystencjalny aspekt wiąże się z uestetycznieniem teologii. Estetyka i w ogóle piękno należą do sfery, którą z jednej strony możemy opisywać w ścisłych kategoriach logiczno-ontologicznych (chociaż nie jest to łatwe), a z drugiej jest nierozerwalnie związana z doświadczeniem.

Jedną z cech myśli współczesnej, stawiającej duży opór klasycznej myśli teologicznej, jest jej antymetafizyczne nastawienie. Natomiast jedną z podstawowych kategorii znamionujących ponowoczesność jest estetyka. Jej natura, przystająca zarówno do dyskursu ontologicznego, jak i fenomenologicznego, wydaje się w takim kontekście stanowić naturalne środowisko, w którym teologia może nawiązać dialog z myślą ponowoczesną, w celu budowania nowej formy teo-ontologii, która nie zrywałaby ze wspaniałą tradycją teologiczną, a jednak byłaby przystająca do wrażliwości i myśli współczesnej.

Słowa kluczowe: teo-ontologia; estetyka; piękno; metafizyka; epistemologia; meta-teologia; dekonstrukcja; postmodernizm.

Abstract. Theo-ontology of beauty in the perspective of late modernity. Today it is more and more often underlined that the theology can no longer be merely intellectual analyse of the Revelation but should relate to specific living the Christianity. That existential dimension implies "aestheticization" of theology. Aesthetics and beauty in general belong to the area that may be described with strict logic-ontological categories (what is not easy), but on the other hand this area is inseparably connected to experience.

One of the features of the contemporary thought, contradicting strongly the classical theology, is its anti-metaphysical approach. On the other hand, aesthetics is one of the categories characterizing the modernity. The nature of aesthetics, that is compatible with the ontological as well as phenomenological discourse, seems to constitute in such a context a natural environment, in which theology may enter in dialogue with the post-modern thought in order to build a new form of theo-ontology, that would not break off with the great theological tradition and simultaneously would be compatible with contemporary sensibility and thought.

Keywords: theo-ontology; aesthetics; beauty; metaphysic; epistemology; meta-theology; deconstruction; postmodernism. 